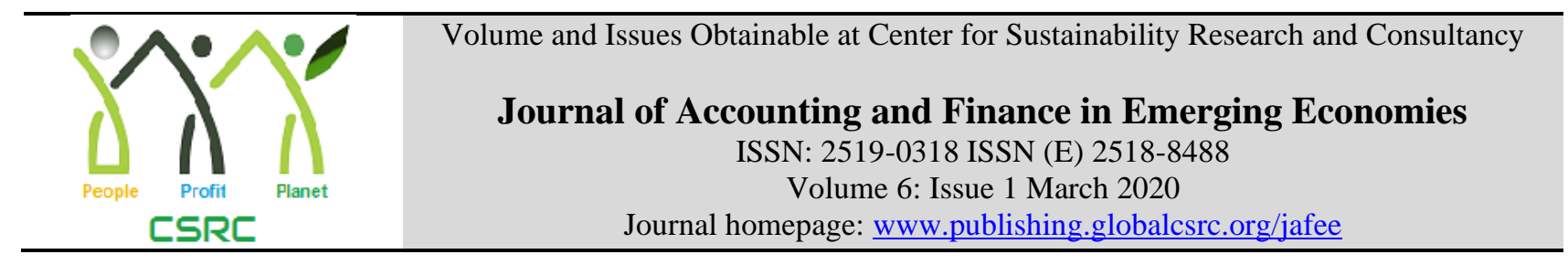

\title{
International Financial Integration through Depositary Receipts (DRs)
}

\author{
${ }^{1}$ Obiyathulla Ismath Bacha, ${ }^{2}$ Norhazlina Ibrahim, ${ }^{3}$ Mansor H. Ibrahim \\ ${ }^{1}$ International Centre for Education in Islamic Finance (INCEIF) Malasia: obiya@ inceif.org \\ ${ }^{2}$ Universiti Sains Islam Malaysia: norhazlina@usim.edu.my \\ ${ }^{3}$ International Centre for Education in Islamic Finance (INCEIF) Malasia: mansorhi@inceif.org
}

\begin{tabular}{l}
\multicolumn{1}{c}{ ARTICLE DETAILS } \\
\hline History \\
Revised format: February 2020 \\
Available Online: March 2020 \\
\\
Keywords \\
Depositary Receipts (Drs), Cross- \\
Listing, OIC Countries, Islamic \\
Finance, Cointegration
\end{tabular}

JEL Classification:

G21, P33, P39

\begin{abstract}
The issue of liquidity and underdevelopment of the Organisation of Islamic Cooperation (OIC) stock markets has caused problems to companies in those countries that seek higher equity capital. One way out of this problem is to employ international markets more intensively by seeking cheaper cost of capital through Depositary Receipts (DRs). Many studies on DRs focused on emerging and developed countries, leaving many OIC countries behind. Thus, this study investigates the financial implication by examining the integration of returns of local and foreign stock markets via American Depositary Receipts (ADRs) and Global Depositary Receipts (GDRs) of OIC countries. Techniques employed in this study are cointegration and the speed of adjustments to examine the existence of integration between the local and foreign stock markets. The study covers a sample of 146 firms from 17 OIC countries that are crosslisted as ADRs or GDRs from 1992 to 2011. The findings show mixed results when some markets provide evidence of integration while others show evidence of segmentation. The study on the integration between DR and home equity markets has practical implications for both the international as well as domestic investors especially on portfolio selection, asset pricing and risk management
\end{abstract}

\section{OPEN ACCESS}

(C) 2020 The authors, under a Creative Commons Attribution-Non

Commercial 4.0

Corresponding author's email address: norhazlina@usim.edu

Recommended citation: Bacha, O. I., Ibrahim, N. \& Ibrahim, M. H., (2020). International Financial Integration through Depositary Receipts (DRs). Journal of Accounting and Finance in Emerging Economies, 6 (1), 301-322

DOI: $10.26710 /$ jafee.v6i1.1076

\section{Introduction}

The capital markets around the world tend to harmonise their policies and regulations due to the pressure of global competition in the last few decades. This financial globalisation is also affecting stock markets within the Organisation of Islamic Cooperation (OIC) ${ }^{1}$. Despite this exposure, a study by the World Bank

1 The Organisation of Islamic Cooperation (OIC), formerly known as the Organisation of the Islamic Conference. It is the secondlargest intergovernmental organisation after the United Nations which has a membership of 57 states spreading over four continents. The Organisation is the collective voice of the Muslim world in ensuring to safeguard and protect the interests of the Muslim world in the spirit of promoting international peace and harmony among various people of the world. 
reveals that many capital markets of the OIC countries remain highly illiquid and segmented, with trading capitalisation concentrating on a few stocks. Out of the total of 57 constituent countries, only 21 stock markets fall under the purview of World Development Indicators (World Bank, 2006). The universal reasons that hinder these stock market developments are the weak legal system and regulations, a limited supply of institutional investors, less support from the private sector, and the lack of transparency and accountability. Besides, most companies in the OIC countries with less developed capital markets have not participated in global consolidation waves and are still pursuing a homemade strategy in developing their own stock market (Hassan \& Suk-Yu, 2007). Apart from that, most OIC stock markets are illiquid and relatively small to most emerging markets and tailing even further behind the developed markets.

Some of these companies need liquidity and enhance their value but are being held down by their domestic stock markets. One of the easiest solutions to this problem is to employ international markets more intensively. In some emerging markets, this internationalisation process is the outcome of companies trying to break away from poor domestic environments with poorly functioning markets and weak institutions (Karolyi, 2004; Torre et al., 2005). Claessens et al. (2003) proposed some form of crossborder linkages with other exchanges to attain cost savings from numerous sources, for example sharing system for equity trading, economy of scale and harmonising rules and requirements between the exchanges with respect to trading and membership. Over the last decades, there has been an increase in the movement of securities market activities to key global financial exchanges, such as London and New York. Many large corporations try to expand their investors' base by listing their stock and raising capital in the market that can offer financing with the lowest costs.

Many approaches have been taken to enhance the capacity and integration of stock markets to promote intra-investment among the OIC countries and the most popular instrument used is Depositary Receipts (DRs). The importance of DR is that it represents ownership of equity shares in a foreign company and it is also one of the popular means to access the international markets. Over the last decade, global trading in DRs has increased dramatically to an all-time high of 150 billion DRs, with a value of $\$ 3.4$ trillion, in 2010 (JP Morgan, 2010). Throughout this period, the number of firms listing their securities via DRs has also increased in the OIC countries (refer to Figure 1). In 1993, only five companies from OIC countries subscribed to DRs, but the number has increased to 146 companies in 2011.

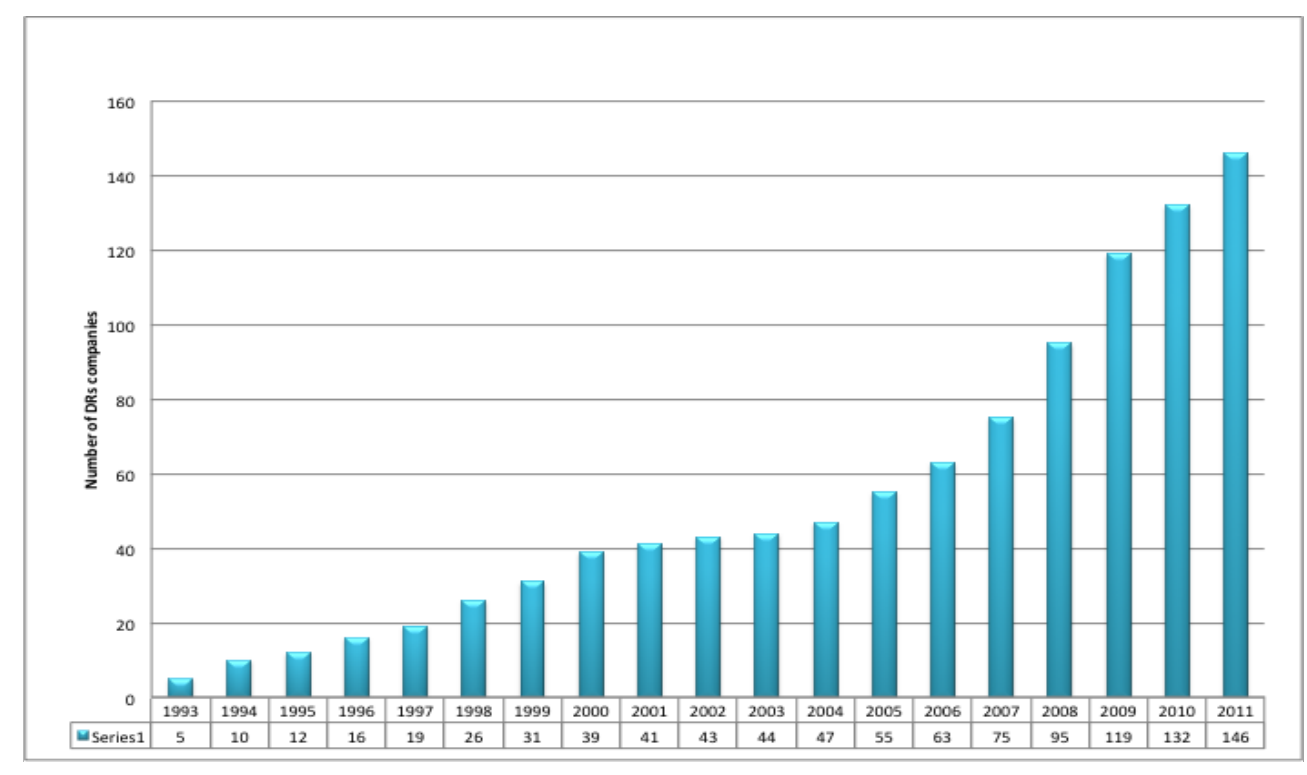

Figure 1: Number of companies that subscribed to DRs (OIC countries) Source: Bank of New York Mellon, 2011 
The critical question is whether these instruments promote integration between the local and foreign stock market. Financial integration has positive impacts on financial stability in the region through more effective distribution of capital, a lower probability of asymmetric shocks, a more robust market. Moreover, it would help to increase the capacity of the economies to absorb shocks and promote growth. On the negative side, intensified financial connections in a area of high investment movement may also instigate the risk of cross-border financial contagion, especially in the interdependent region's (Yu et al., 2010). According to migration view, internalisation through cross-listing will induce a shift of trade from local market to major international financial market. This condition inevitably hurts the trading and liquidity of the local stock market. As a result, it is vital to have appropriate measures or indicators to monitor the development and assess the progress of financial integration in the region.

Based on the law of one price (LOOP), cross-listed shares represent the same assets and therefore should have identical prices if they are converted into the same currency. Based on this analogy, one frequently used definition of financial integration is that financial markets are said to be integrated when the LOOP holds. As with so many techniques available, several studies uphold the LOOP and conclude no arbitrage opportunities exist (Alaganar \& Bhar, 2002; Kato et al., 1991; Rosenthal \& Young, 1990; Wahab et al., 1992). Kato et al. (1991) directly compared the market prices of ADRs with their underlying foreign stocks (eight from Australia and Japan and seven from England) for differences and correlations. They found no significant differences between the prices of the two identical types of claims and concluded that no arbitrage opportunities exist between international capital markets encompassed by their study.

However, Wahab et al. (1992) differed and found clashing evidence of this LOOP. They found that there are possible differences in return volatilities of ADRs and their respective underlying shares due to market imperfections, differential trading frequency, and market microstructure effects. Although several empirical studies support the notion of LOOP with or without the aid of arbitrage process; nevertheless, not all studies reach the same conclusion. Some studies discover the LOOP is often violated (Chan et al., 2008; Froot \& Dabora, 1999; Gagnon \& Karolyi, 2010).

Thus, the objective of this study is to examine from an empirical standpoint the impact of DRs on the integration between the OIC and foreign stock markets. Most of the studies concentrated on emerging and developed countries but did not look into the DR activities of OIC countries. This means that there is still a lack of knowledge towards the impact of DR activities on this particular group of cross-listed shares.

\section{Methodology}

The financial integration between these markets is determined by two methods. The first method is by examining the cointegration between the price of cross-listed and home-market shares, whilst the second methods measure the speed of convergence of the price deviations from the parity back to the equilibrium of these shares.

\subsection{Price Parity for Cross-Listed Pairs Across Time and Cointegration}

As mentioned earlier, one frequently used definition of financial integration is when the LOOP holds. Theoretically, since a DR and its underlying share are identical and comparable assets, logically the price of a DR in the foreign market should be similar to the value of its underlying share in home market. Any identical or comparable assets that trade across different markets should produce a similar price, measured by cross-market premium (DR price minus home-market share price). Consequently, in a fully integrated market, the value of cross-market premium should be nil or zero.

Since the home-market prices use home markets' currency, thus we need to firstly convert these homemarket prices into US dollars at the exchange rate. For the purpose of this study, PH is equivalent to the price of home share value after converting the home market shares in home currency (PHLC) to US dollar 
using the exchange rate $\left(\mathrm{S}_{\mathrm{t}}\right)$.

$$
\mathrm{PH}_{\mathrm{t}}=\mathrm{PHLC}_{\mathrm{t}} * \mathrm{~S}_{\mathrm{t}}
$$

$\mathrm{PDR}_{\mathrm{t}}$ on the other hand is the price of DRs expressed in US dollar (PD) after being adjusted for the DR ratio $(\mathrm{R})$.

$$
\mathrm{PDR}_{\mathrm{t}}=\mathrm{R} * \mathrm{PD}
$$

In this study, the price differences for each pair are being analysed in detail. First, the absolute price discrepancy is simply the measure in dollars of the difference between prices of domestic market and DRs (PH-PDR)t. Then, the log-price differences are calculated by taking the natural logarithm of price $\left(\mathrm{PH}_{\mathrm{t}}\right)$ expressed in US dollars divided by $\mathrm{DRs}$ price $\left(\mathrm{PDR}_{\mathrm{t}}\right)$ and can be expressed in this formulae $\left(\mathrm{Ln}(\mathrm{PH} / \mathrm{PDR})_{\mathrm{t}}\right)$.

$$
\text { Price Difference }=\mathrm{Ln}\left(\mathrm{PH}_{t} / \mathrm{PDR}_{\mathrm{t}}\right)=\mathrm{DR} \text { Discount }(\text { Premium })
$$

If the theory of LOOP holds, the price and return of these cross-listed shares should be similar. However, in some cases, this theory is not applicable as a DR may be sold at either a discount or a premium to the value of the underlying asset mostly due to exchange rate anticipations and the transaction costs linked to conversion of the DR (Arquette et al., 2008). If the cross-market difference is positive, we denote it DR discount. It means that the DR shares trade lower than the values attached to the underlying shares in the home market. Otherwise, it is denoted DR premium, meaning that the DR shares selling abroad have higher prices than the similar home-market shares.

Following the LOOP, these shares that trade across different economies should generate not only similar price but also the same return. If there is a small deviation or discrepancy across economies as calculated by the cross-market return dispersion, it will imply that the equity markets are fully integrated in the sense of return convergence. For this analogy, the daily changes in Ln (PH/PDR)t, or the daily return differences in the price deviations are computed as well.

$$
\Delta \operatorname{Ln}(\mathrm{PH} / \mathrm{PDR})_{\mathrm{t}}=\left[\mathrm{Ln}\left(\mathrm{PH}_{\mathrm{t}} / \mathrm{PDR}_{\mathrm{t}}\right)\right]_{\mathrm{t}}-\left[\mathrm{Ln}\left(\mathrm{PH}_{\mathrm{t}} / \mathrm{PDR}_{\mathrm{t}}\right)\right]_{\mathrm{t}-1}
$$

There is evidence of integration if the prices of the DR and underlying shares are cointegrated. This means that the difference between these two prices is a mean-reverting, I(0) process. Based on the above, the first hypothesis can be formally stated as follows:

H1: If the prices of the DR and its underlying shares are cointegrated, there is an indication that the markets are integrated.

All these data on DRs prices, underlying share prices, and price differences will be tested on several tests such as stationary test and cointegration test. The cointegration test would test whether or not the prices of the DR and home-market shares will go back to the equilibrium. However, the determination of unit root or stationary test is important before the cointegration test is performed.

The unit root test is very important in the context of time series analysis so as to check the level of stationarity of the data as to advance further in testing the cointegration. Furthermore, it is also a wellknown fact that almost all financial data are non-stationary in their original form (Doidge et al., 2009). Thus, Augmented Dickey Fuller (ADF) was applied in this study. 


\subsection{The Speed of Convergence}

In addition to using the cointegration technique, we also applied another technique to assess integration. Another approach to measuring this is by capturing the speed of adjustment coefficients. As to measure this speed of adjustment of the deviations from parity, rolling and recursive regressions procedures (Autoregressive Model) were applied. Higher convergence speeds reflect a quicker convergence to LOOP, hence stronger financial integration. The persistence of shocks is estimated using the Augmented Dickey-Fuller model, with one autoregressive component and other lagged differences. That is, we estimate the following model $\left(\mathrm{x}=\mathrm{Ln}(\mathrm{PH} / \mathrm{PDR})_{\mathrm{t}}\right)$ :

$$
\Delta x_{t}=\beta x_{t-1}+\sum_{j=1}^{k} \emptyset_{j} \Delta x_{t-j}+\varepsilon_{t}
$$

The equation measures the change in the premium/discount the differences between the price of the underlying stock and the price of the DR. Put differently, $\beta$ provides a measure of the speed of convergence of the premium back to its mean. The higher values of these coefficients, as the sample rolls forward, can be interpreted as a higher degree of financial integration (Pascual, 2003; Yeyati et al., 2009).

The value of $\beta$ is a greater contributor to the degree of financial integration and thus the hypothesis is stated as follows:

H2: If the value of $\beta$ is increasing, there is an indication that the markets are integrated.

\subsection{Data Descriptions and Model Specification}

For this study, we used time-series data from 1992-2011. This information is derived from the "DR Directory" of the Bank of New York Mellon ${ }^{2}$ as of 31 December 2011 and the numbers are gathered from the active DRs. These data collections start from the Bank of New York ${ }^{3}$ since it has a rather complete DR Directory that contains information on current DR activities.

\section{Analysis and Findings}

The summary statistics of DRs in the OIC countries as of 2011 are presented in Table 1. Overall, Turkey led the pack by having 46 DRs, followed by Indonesia (36), Kazakhstan (26), and Egypt (25). The breakdown by DRs comprising of ADRs and GDRs are clearly laid out in Table 1. Generally, the pattern varied by country. Specifically, by looking at the pattern in Table 1, all non-Asian countries were likely to subscribe to GDRs ${ }^{4}$, except for Turkey. On the other hand, Asian countries such as Malaysia and Indonesia dominated the issuance of ADRs, with the exception of Bangladesh and Pakistan.

2 Retrieved October 20, 2011 from http://www.adrbnymellon.com/.

3 These data can be retrieved October 20, 2011 from http://www.adrbnymellon.com/dr directory.jsp?paramUserType=broker and according to Kim, BNY database was substantially more reliable and comprehensive than that of Citibank.

4 The exchanges involved in GDR are London and Luxemburg Stock Exchanges. 
Table 1: The Summary of DRs as at December 2011

\begin{tabular}{|l|l|l|l|l|l|l|}
\hline No & Country & $\begin{array}{l}\text { Compan } \\
\text { ies }\end{array}$ & ADRs & $\begin{array}{l}\text { GDR } \\
\text { S }\end{array}$ & $\begin{array}{l}\text { Total } \\
\text { DRs }\end{array}$ & $\begin{array}{l}\text { Effective } \\
\text { year } \\
\text { of listing }\end{array}$ \\
\hline 1 & Bahrain & 3 & 0 & 6 & 6 & 2006 \\
\hline 2 & Bangladesh & 1 & 0 & 1 & 1 & 2005 \\
\hline 3 & Egypt & 13 & 5 & 20 & 25 & 1996 \\
\hline 4 & Indonesia & 36 & 36 & 0 & 36 & 1994 \\
\hline 5 & Jordan & 3 & 2 & 2 & 4 & 1997 \\
\hline 6 & Kazakhstan & 15 & 2 & 24 & 26 & 1999 \\
\hline 7 & Kuwait & 1 & 0 & 2 & 2 & 2008 \\
\hline 8 & Lebanon & 4 & 1 & 5 & 6 & 1997 \\
\hline 9 & Malaysia & 10 & 10 & 0 & 10 & 1983 \\
\hline 10 & Morocco & 1 & 0 & 2 & 2 & 1996 \\
\hline 11 & Nigeria & 6 & 0 & 10 & 10 & 1998 \\
\hline 12 & Oman & 1 & 0 & 2 & 2 & 2005 \\
\hline 13 & Pakistan & 9 & 2 & 14 & 16 & 1994 \\
\hline 14 & Qatar & 2 & 0 & 4 & 4 & 1999 \\
\hline 15 & Tunisia & 1 & 0 & 2 & 2 & 1998 \\
\hline 16 & Turkey & 37 & 26 & 20 & 46 & 1993 \\
\hline 17 & UAE & 3 & 1 & 3 & 4 & 2006 \\
\hline & TOTAL & $\mathbf{1 4 6}$ & $\mathbf{8 5}$ & $\mathbf{1 1 7}$ & $\mathbf{2 0 2}$ & \\
\hline
\end{tabular}

\section{Source: Bank of New York Mellon and Datastream}

In Table 1, the number of companies taking up DRs may not be equal to the number of DRs. This is because the same companies may have subscribed to both ADR and GDR at the same time. For example, in Egypt there were 13 companies that subscribed to DRs and yet they issued 5 ADRs and 20 GDRs. Meanwhile, the effective start-up year for DR varied across countries, as early as 1983 for Malaysia and as late as 2008 for Kuwait.

Based on the total issues of 202 DRs, more than half of DRs were GDRs. The higher number of GDR issues compared to ADRs indicated that these foreign companies preferred London or Luxembourg to the US. According to Doidge et al. (2009), by 2005 New York's shares exceeded London cross-listings by only $59 \%$ compared to $78 \%$ in 1998. Many argued that London has become more competitive in attracting foreign listings than New York. A popular justification for this decrease in foreign listings is that the introduction of the Sarbanes-Oxley Act (SOX) in 2002 that imposed severe costs on companies and their managers and thus made the US listings significantly less attractive to these foreign firms. Nonetheless, by referring to Table 1, countries such as Indonesia, Malaysia, and Turkey still preferred ADRs compared to GDRs. This is because the US market is known for their legal structure, stringent nature of SEC of USA requirements, and most importantly higher transparency in financial disclosure (Doidge et al., 2009; Martin, 1995; Sevic et al., 2010). 


\subsection{Price Parity for Cross-Listed and Home-Market Shares}

As to arrive at the final sample, the screening of data was implemented5Initially, the number of companies was 146, but after applying these screens, we identified a subset of 34 potential home and cross-listed pairs. The list of companies used for this analysis is in Appendix 1. Out of these 34 home and cross-listed pairs, almost $85 \%$ of these companies subscribed to ADR, whilst the rest were dominated by GDR issuance with a share of $25 \%$. ADR/GDR Level I clearly led with a $71 \%$ (24 companies), whilst $11 \%$ (4 companies) were GDR Regulation S, 9\% of ADR Rule 144A (3 companies) and ADR Level III (3 companies) respectively. Moreover, all the samples used US dollar as the currency although a few of them traded on the Stock Exchange Automated Quotation (SEAQ) International, London.

Tables 2 and 3 present the summary statistics of the daily price discrepancy for each company and country. In Table 2, the absolute price discrepancy was simply the measure in dollars of the difference between prices in host and domestic markets (PH-PDR)t. For the final sample, the average price differences was negative USD1.2, which implied that, on average, DRs traded at a small premium relative to their home-market share counterparts. Across countries, we observe interesting patterns in the mean and median price differences. For countries such as Egypt, Indonesia, Lebanon, Nigeria, and Qatar, the mean prices of DR were higher than their underlying share prices in home market. The highest difference came from Egyptian companies, at -USD4.77. Indonesia had the lowest value of almost zero in their price differences. On the other hand, relative to their home shares, DRs from Malaysia and Turkey were selling at a discount averaging of USD 0.26 and 0.8 respectively. Across countries, Egypt had the highest standard deviation of USD6.07, whilst Indonesia had the lowest standard deviation of price differences of USD0.03.

\section{Table 2: The Exact Value of the Daily Price Discrepancies (PH-PDR)t}

\begin{tabular}{|l|l|l|l|l|l|}
\hline & Mean & Median & $\begin{array}{l}\text { Maximu } \\
\mathrm{m}\end{array}$ & Minimum & Std. Dev. \\
\hline ALL AVERAGE & $\mathbf{- 1 . 2 1}$ & $\mathbf{- 0 . 2 8}$ & $\mathbf{5 . 1 4}$ & $\mathbf{- 7 . 6 1}$ & $\mathbf{2 . 6 0}$ \\
\hline Egypt & -4.77 & -1.56 & 5.33 & -23.91 & 6.07 \\
Indonesia & -0.01 & -0.01 & 0.15 & -0.12 & 0.03 \\
Malaysia & 0.26 & 0.15 & 1.41 & -1.17 & 0.47 \\
Turkey & 0.80 & 0.82 & 2.04 & -0.41 & 0.52 \\
Other - Lebanon & -0.40 & -0.38 & 0.65 & -1.40 & 0.32 \\
Other - Nigeria & -0.02 & -0.02 & 0.02 & -0.08 & 0.02 \\
Other - Qatar & -4.36 & -0.93 & 26.38 & -26.19 & 10.77 \\
\hline
\end{tabular}

Table 3 shows the relative price differences. The average relative price difference was zero, which implied that, on average, DRs trade at a similar value relative to their home-market share counterparts. Across countries, we observe interesting patterns in the mean price differences. For Malaysia and Turkey, their DRs trade at discounts of $43 \%$ and $23 \%$ respectively. On the other hand, relative to their home shares, DRs from Egypt, Lebanon, Nigeria, and Qatar trade at premiums of $64 \%, 6 \%, 22 \%$, and $10 \%$ respectively. Indonesia, on the other hand, produced zero relative price differences, implying that all cross-listed share prices were trading at the same price to their underlying shares in home market. Across countries, Malaysia had the highest standard deviation of $67 \%$. 


\section{Table 3: The Relative Value of the Daily Price Discrepancies [Ln(PH/PDR)T]}

\begin{tabular}{|l|l|l|l|l|l|}
\hline & Mean & Median & Maximum & Minimum & Std. Dev. \\
\hline ALL & & & & & \\
AVERAGE & 0.000 & 0.000 & 0.000 & 0.000 & 0.000 \\
\hline Egypt & -0.644 & -0.601 & -0.176 & -1.105 & 0.182 \\
Indonesia & $-7 \mathrm{E}-03$ & $-5 \mathrm{E}-03$ & $2 \mathrm{E}-01$ & $-2 \mathrm{E}-01$ & $5 \mathrm{E}-02$ \\
Malaysia & 0.438 & 0.092 & 2.061 & -0.479 & 0.665 \\
Turkey & 0.231 & 0.233 & 0.486 & -0.030 & 0.114 \\
$\begin{array}{l}\text { Other } \\
\text { Lebanon }\end{array}$ & -0.057 & -0.055 & 0.146 & -0.191 & 0.045 \\
$\begin{array}{l}\text { Other - Nigeria } \\
\text { Other - Qatar }\end{array}$ & -0.219 & -0.239 & 0.198 & -0.689 & 0.171 \\
\hline
\end{tabular}

Based on the summary of the exact and relative value of the daily price discrepancy, the prices of crosslisted and home market shares were trading at more or less similar value. However, there is a need to conduct more tests to confirm this descriptive finding. In the next section, the test of cointegration, the speed of convergence, and concordance index are being explored in great detail as to examine the existence of integration.

However, before delving into the cointegration test, it is best to have a first glance at the price differences for each country shown in Figures 2 to 6.
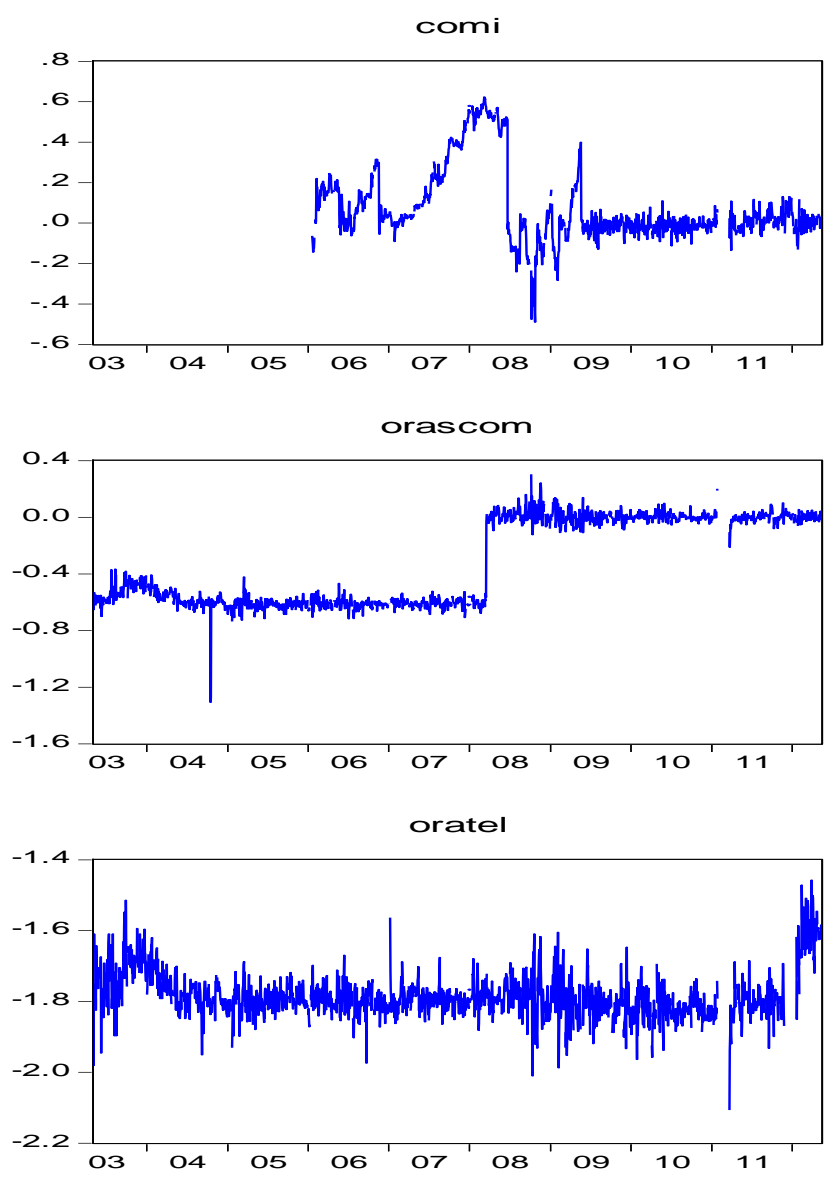

FigURE 2: PRICE DIFFERENCES FOR DR COMPANIES - EGYPT 
Figure 2 presents the graphical illustration of price differences for Egypt. It seems that Oratel company had a rather smaller standard deviation in price deviation compared to Comi and Orascom, but the average price differences oscillated around 1.8, higher than the other two companies. Figure 3 displays the price differences for Indonesian companies and the volatility of the price differences were less compared to the Egyptian companies. Most of the price differences for Indonesian companies moved around zero with a small standard deviation.
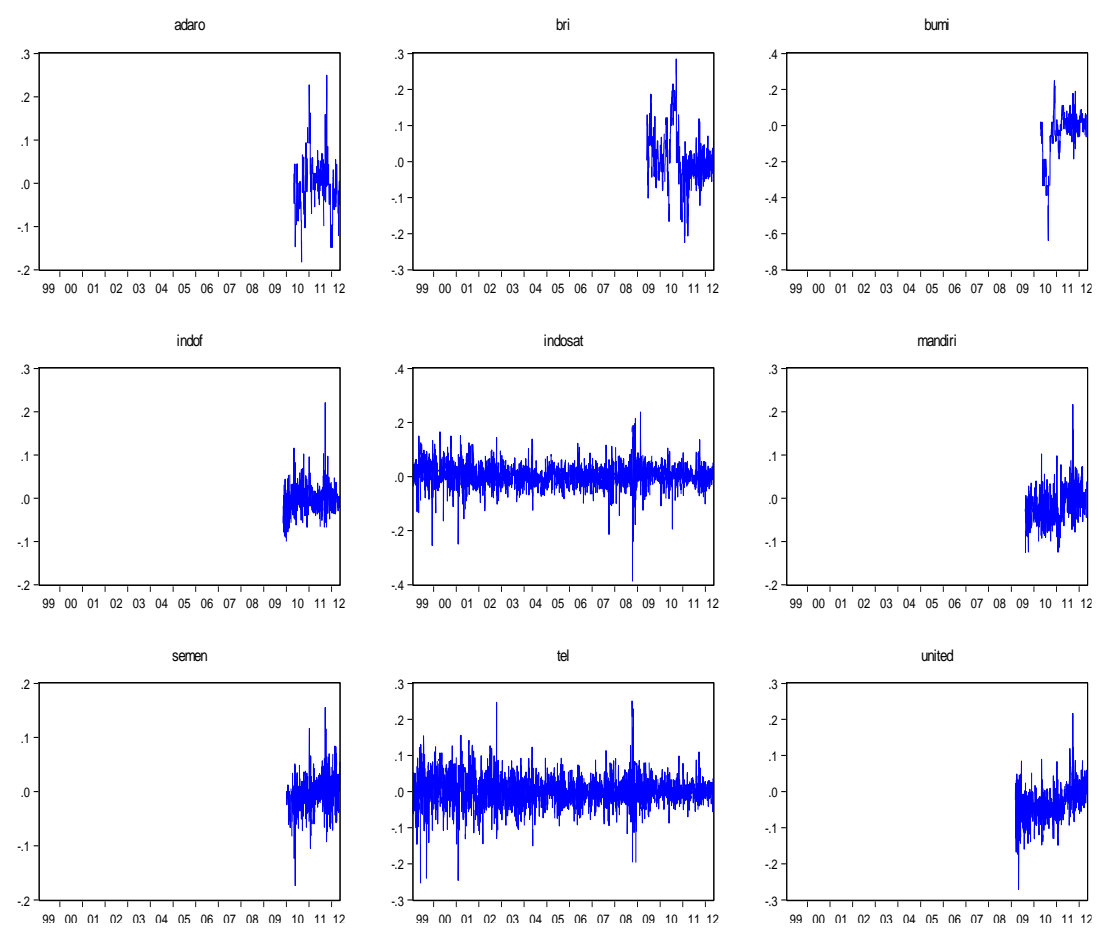

FigURE 3: PRICE DIFFERENCES FOR DR COMPANIES - INDONESIA

Malaysia, on the other hand, showed a rather different story. Out of all these countries, Malaysia probably had the highest volatility in terms of price differences. All companies showed a wide standard deviation of price differences in Figure 4. The same patterns applied to Turkish companies in Figure 5. Most companies had a wide standard deviation except for two companies, Turkcel and Koc. For these two firms, the price differences oscillated around zero with a small standard deviation.

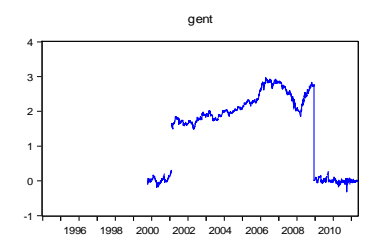

mbf

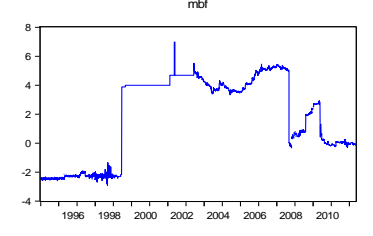

top

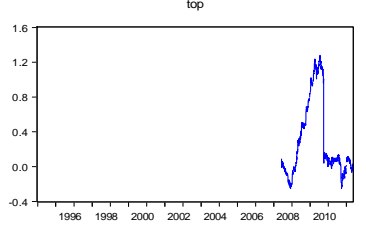

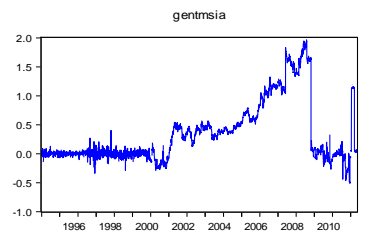

mbnk
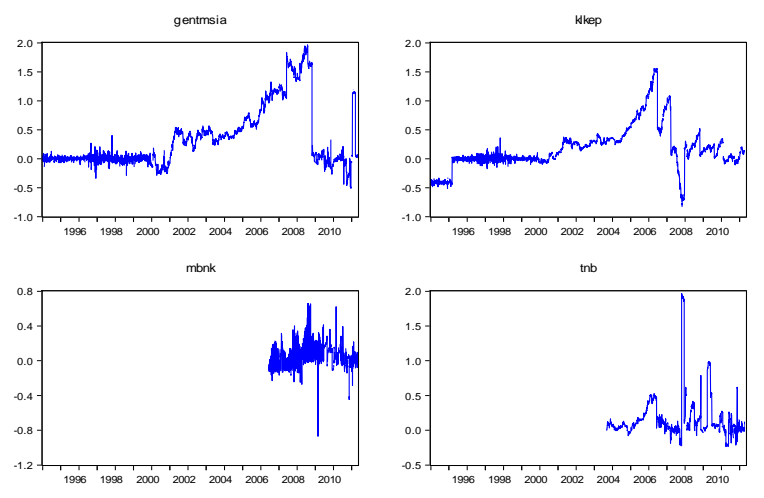

tnb

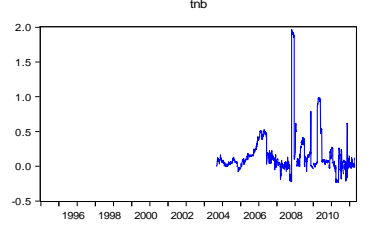

Figure 4: PRICE DIFFERENCES FOR DR COMPANIES - MALAYSIA 

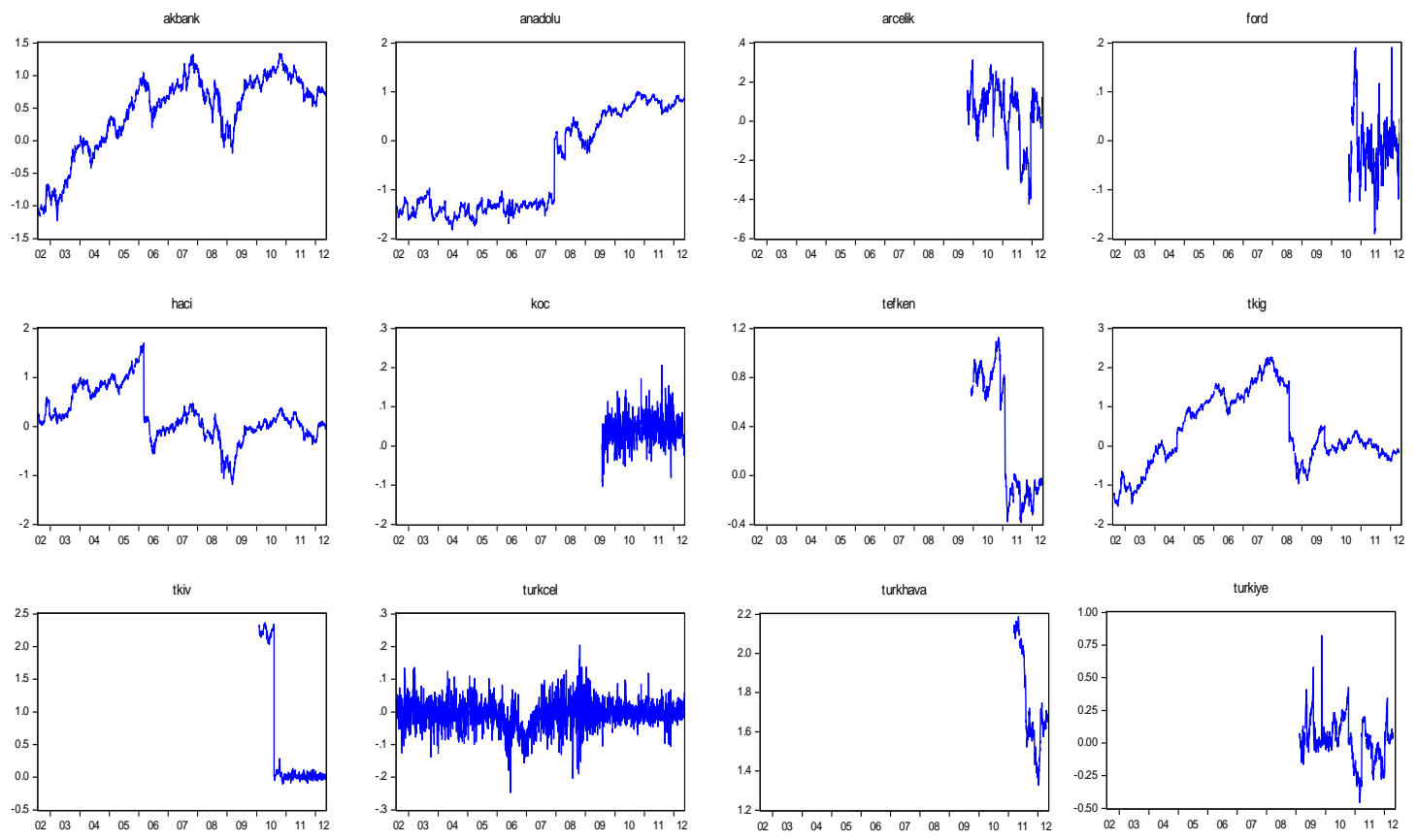

FIGURE 5: PRICE DIFFERENCES FOR DR COMPANIES - TURKEY
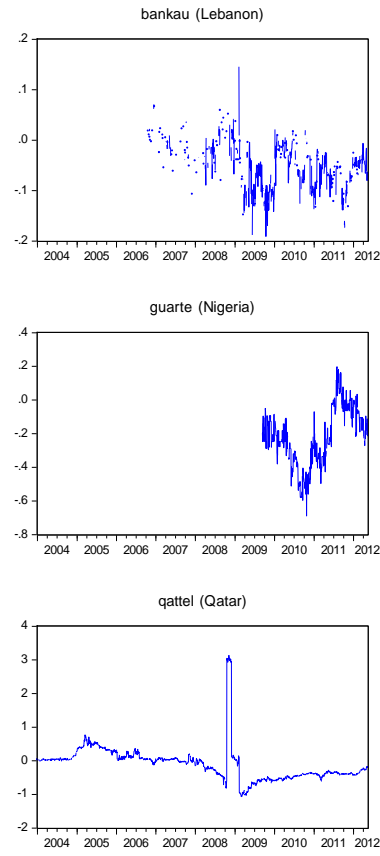

FIGURE 6: PRICE DIFFERENCES FOR DR COMPANIES - OTHERS

Figure 6 shows the patterns of price discrepancies of three companies from three different countries. Bankau from Lebanon and Guarte from Nigeria displayed rather high volatility compared to Qatari company, Qattel. Qattel's price differences were rather stable throughout 2004 until 2011. However it experienced high volatility in 2008 and 2009, when the price differences jumped to 3. 


\subsection{Cointegration Test}

Before establishing whether or not the daily stock prices are indeed cointegrated, first there is a need to prove that each of these daily prices is non-stationary with a unit root or I(1) when tested individually. Table 4 presents the necessary evidence to support these claims. Using Augmented Dickey-Fuller (ADF) statistics, we tested all the variables by setting the null hypothesis of the series of having a unit root. We found that they were non-stationary in the level form (both for home and DRs' share prices in Columns 1 and 2) and stationary in the first difference. It can be seen that all variables were stationary in the first difference or simply were I(1) process.

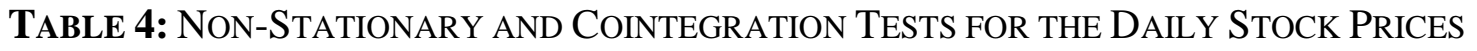

\begin{tabular}{|c|c|c|c|c|c|}
\hline EGYPT (3) & $\begin{array}{l}\text { ADF } \\
\text { Level } \\
\text { (Home) } \\
(1)\end{array}$ & $\begin{array}{l}\text { ADF } \\
\text { Level } \\
\text { (DR) } \\
(2)\end{array}$ & $\begin{array}{l}\text { ADF First } \\
\text { Difference } \\
\text { (Home) } \\
\text { (3) }\end{array}$ & $\begin{array}{l}\text { ADF First } \\
\text { Difference } \\
\text { (DR) } \\
\text { (4) }\end{array}$ & $\begin{array}{l}\text { Cointegration } \\
\text { at } 5 \% \\
(5)\end{array}$ \\
\hline Comi & 0.952 & 0.386 & 0.0001 & 0.0001 & Yes \\
\hline Orascom & 0.824 & 0.307 & 0.0000 & 0.0001 & No \\
\hline Oratel & 0.230 & 0.678 & 0.0001 & 0.0001 & Yes \\
\hline $\begin{array}{l}\text { INDONESIA } \\
\text { (9) }\end{array}$ & $\begin{array}{l}\text { ADF } \\
\text { Level } \\
\text { (Home) }\end{array}$ & $\begin{array}{l}\text { ADF } \\
\text { Level } \\
\text { (DR) }\end{array}$ & $\begin{array}{l}\text { ADF First } \\
\text { Difference } \\
\text { (Home) }\end{array}$ & $\begin{array}{l}\text { ADF First } \\
\text { Difference } \\
\text { (DR) }\end{array}$ & $\begin{array}{l}\text { Cointegration } \\
(5 \%)\end{array}$ \\
\hline Adaro & 0.487 & 0.993 & 0.0000 & 0.0000 & No \\
\hline Bri & 0.802 & 0.490 & 0.0001 & 0.0000 & Yes \\
\hline Bumi & 0.899 & 0.989 & 0.0000 & 0.0000 & No \\
\hline Indof & 0.675 & 0.651 & 0.0001 & 0.0000 & Yes \\
\hline Indosat & 0.293 & 0.264 & 0.0001 & 0.0001 & Yes \\
\hline Mandiri & 0.793 & 0.283 & 0.0001 & 0.0000 & Yes \\
\hline Semen & 0.989 & 0.216 & 0.0001 & 0.0000 & Yes \\
\hline Tel & 0.588 & 0.589 & 0.0001 & 0.0000 & Yes \\
\hline United & 0.943 & 0.310 & 0.0001 & 0.0000 & Yes \\
\hline $\begin{array}{l}\text { MALAYSIA } \\
\text { (7) }\end{array}$ & $\begin{array}{l}\text { ADF } \\
\text { Level } \\
\text { (Home) }\end{array}$ & $\begin{array}{l}\text { ADF } \\
\text { Level } \\
\text { (DR) }\end{array}$ & $\begin{array}{l}\text { ADF First } \\
\text { Difference } \\
\text { (Home) }\end{array}$ & $\begin{array}{l}\text { ADF First } \\
\text { Difference } \\
\text { (DR) }\end{array}$ & $\begin{array}{l}\text { Cointegration } \\
(5 \%)\end{array}$ \\
\hline Gent & 0.782 & 0.479 & 0.0001 & 0.0000 & No \\
\hline Gentmsia & 0.273 & 0.015 & 0.0001 & 0.0010 & Yes \\
\hline Klkep & 0.787 & 0.959 & 0.0001 & 0.0001 & Yes \\
\hline Mbf & 0.615 & 0.070 & 0.0000 & 0.0000 & Yes \\
\hline Mbnk & 0.196 & 0.019 & 0.0001 & 0.0000 & Yes \\
\hline Tnb & 0.131 & 0.0001 & 0.0001 & 0.0000 & Yes \\
\hline Top & 0.445 & 0.578 & 0.0001 & 0.0000 & No \\
\hline TURKEY (12) & $\begin{array}{l}\text { ADF } \\
\text { Level } \\
\text { (Home) }\end{array}$ & $\begin{array}{l}\text { ADF } \\
\text { Level } \\
\text { (DR) }\end{array}$ & $\begin{array}{l}\text { ADF First } \\
\text { Difference } \\
\text { (Home) }\end{array}$ & $\begin{array}{l}\text { ADF First } \\
\text { Difference } \\
\text { (DR) }\end{array}$ & $\begin{array}{l}\text { Cointegration } \\
(5 \%)\end{array}$ \\
\hline Akbank & 0.194 & 0.000 & 0.0001 & 0.0001 & No \\
\hline Anadolu & 0.436 & 0.349 & 0.0001 & 0.0001 & No \\
\hline Arcelik & 0.083 & 0.582 & 0.0000 & 0.0000 & - \\
\hline Ford & 0.222 & 0.555 & 0.0001 & 0.0000 & No \\
\hline Haci & 0.155 & 0.577 & 0.0001 & 0.0001 & No \\
\hline Koc & 0.441 & 0.636 & 0.0001 & 0.0000 & Yes \\
\hline Tefken & 0.356 & 0.622 & 0.0000 & 0.0000 & No \\
\hline
\end{tabular}




\begin{tabular}{|c|c|c|c|c|c|}
\hline $\begin{array}{l}\text { Tkig } \\
\text { Tkiv } \\
\text { Turkcel } \\
\text { Turkhava } \\
\text { Turkiye }\end{array}$ & $\begin{array}{l}0.361 \\
0.211 \\
0.138 \\
0.541 \\
0.308\end{array}$ & $\begin{array}{l}0.083 \\
0.497 \\
0.003 \\
- \\
0.336\end{array}$ & $\begin{array}{l}0.0001 \\
0.0000 \\
0.0001 \\
0.0001 \\
0.0000\end{array}$ & $\begin{array}{l}0.0001 \\
0.0000 \\
0.0001 \\
- \\
0.0000\end{array}$ & $\begin{array}{l}\text { No } \\
\text { No } \\
\text { Yes } \\
- \\
\text { Yes }\end{array}$ \\
\hline LEBANON & $\begin{array}{l}\text { ADF } \\
\text { Level } \\
\text { (Home) }\end{array}$ & $\begin{array}{l}\text { ADF } \\
\text { Level } \\
(\mathrm{DR})\end{array}$ & $\begin{array}{l}\text { ADF First } \\
\text { Difference } \\
\text { (Home) }\end{array}$ & $\begin{array}{l}\text { ADF First } \\
\text { Difference } \\
\text { (DR) }\end{array}$ & $\begin{array}{l}\text { Cointegration } \\
(5 \%)\end{array}$ \\
\hline Bankau & & 0.485 & & 0.0000 & No \\
\hline NIGERIA & $\begin{array}{l}\text { ADF } \\
\text { Level } \\
\text { (Home) }\end{array}$ & $\begin{array}{l}\text { ADF } \\
\text { Level } \\
\text { (DR) }\end{array}$ & $\begin{array}{l}\text { ADF First } \\
\text { Difference } \\
\text { (Home) }\end{array}$ & $\begin{array}{l}\text { ADF First } \\
\text { Difference } \\
\text { (DR) }\end{array}$ & $\begin{array}{l}\text { Cointegration } \\
(5 \%)\end{array}$ \\
\hline Guarte & 0.027 & 0.798 & 0.0000 & 0.0001 & Yes \\
\hline QATAR & $\begin{array}{l}\text { ADF } \\
\text { Level } \\
\text { (Home) }\end{array}$ & $\begin{array}{l}\text { ADF } \\
\text { Level } \\
\text { (DR) }\end{array}$ & $\begin{array}{l}\text { ADF First } \\
\text { Difference } \\
\text { (Home) }\end{array}$ & $\begin{array}{l}\text { ADF First } \\
\text { Difference } \\
\text { (DR) }\end{array}$ & $\begin{array}{l}\text { Cointegration } \\
(5 \%)\end{array}$ \\
\hline Qattel & 0.058 & 0.255 & 0.0001 & 0.0001 & No \\
\hline
\end{tabular}

\section{All the values are $p$ value}

In the last column 5, the results of the Johansen-Juselius likelihood cointegration test showed the existence of long run co-movement between home and DR market shares at 5\% significance level for certain companies. Evidence of cointegration implied that the relationship among the variables was not spurious, evidentially there were in equilibrium in the long run. In other words, even though these variables may have diverged in the short run, in the long run however they would converge. Table 6 shows rather mixed results across countries. It shows that out all of these 34 companies, only 53\% (18 companies) show evidence of cointegration. Most of these companies came from Egypt (2), Indonesia (7), Malaysia (5), Turkey (3), and Nigeria (1). The test found that there is a cointegrating vector at $95 \%$ significance level on the basis of Maximal Eigenvalue and Trace Stochastic Test. Indonesia dominated with $78 \%$ of the subsample showing evidence of integration. Malaysia came in second with $71 \%$, while Egypt came in third with $67 \%$. However, Turkey had only $25 \%$ companies that were cointegrated.

\section{TABLE 5: SUMMARY OF COMPANIES - COINTEGRATION TEST}

\begin{tabular}{|l|l|l|l|}
\hline & $\begin{array}{l}\text { Number of } \\
\text { Total Number } \\
\text { of Companies } \\
\text { Country }\end{array}$ & $\begin{array}{l}\text { Cointegrate } \\
\mathbf{d}\end{array}$ & $\begin{array}{l}\text { Percentage } \\
(\mathbf{\%})\end{array}$ \\
Egypt & 3 & 2 & $\mathbf{6 7 \%}$ \\
Indonesia & 9 & 7 & $\mathbf{7 8 \%}$ \\
Malaysia & 7 & 5 & $\mathbf{7 1 \%}$ \\
Turkey & 12 & 3 & $\mathbf{2 5 \%}$ \\
Others & 3 & 1 & $\mathbf{3 3 \%}$ \\
\hline & & $\mathbf{1 8}$ & $\mathbf{5 3 \%}$ \\
TOTAL & $\mathbf{3 4}$ & & \\
\hline
\end{tabular}

Basically, the results in Table 5 show that $47 \%$ of the DRs in the sample violated the LOOP and there was no integration between these markets. Instead of analysing the cointegration, it would be interesting to examine the speed of convergence. The speed of convergence will be discussed in great detail in the next section. 


\subsection{The Speed of Convergence}

As mentioned earlier in the research design section, the speed of adjustment of the deviations from parity was measured using rolling and recursive regressions procedures (Autoregressive Model). Higher convergence speeds reflect a quicker convergence to LOOP, hence stronger financial integration. In order to measure this, the ADF model with one autoregressive component and other lagged differences were applied.

$$
\Delta \mathrm{x}_{\mathrm{t}}=\beta \mathrm{x}_{\mathrm{t}-1}+\sum_{\mathrm{j}=1}^{\mathrm{k}} \emptyset_{\mathrm{j}} \Delta \mathrm{x}_{\mathrm{t}-\mathrm{j}}+\varepsilon_{\mathrm{t}}
$$

The main interest is to calculate the value of $\beta$. This coefficient provides a measure of the speed of convergence of the premium back to its mean.

Graphically, a greater speed of adjustment should be reflected if the value of $\beta$ keeps on increasing (regardless of the positive and negative value). Figures 7 to 11 show the estimates for those coefficients for each company in various countries. Overall, the process of integration did not experience any significant changes for all the countries. For example, none of the Malaysian companies showed a greater speed of adjustment except for KLKep but only for a period of six years, from 1995 until 2002. The coefficient estimates started at 0 and then increased to almost 30\% in year 2002. But then the coefficient estimates for company KLKep reduced after the turning point in 2002 and remained rather stable around zero after 2007.

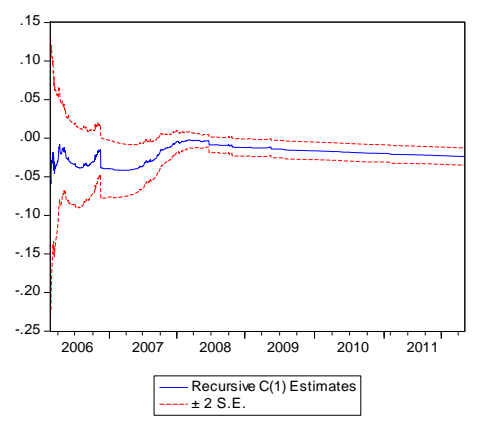

Comit

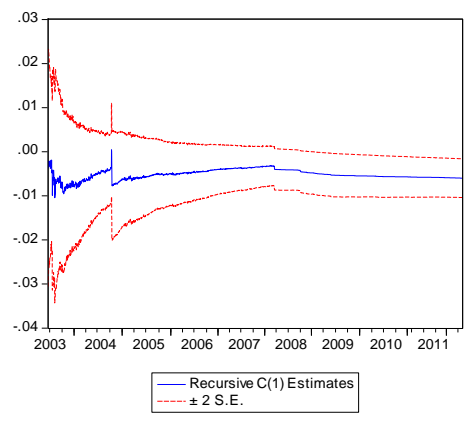

Orascom

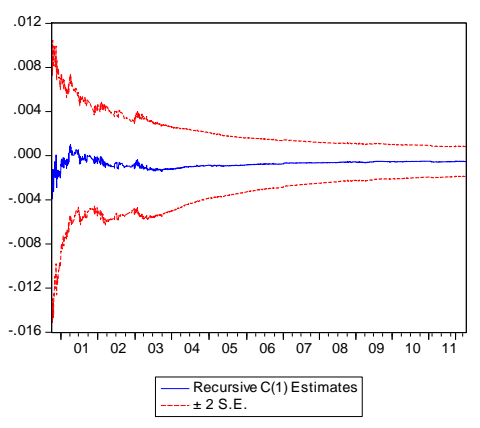

Oratel

FiguRE 7: THE SPEED OF ADJUSTMENT COEFFICIENTS $(B)$ - EGYPT 


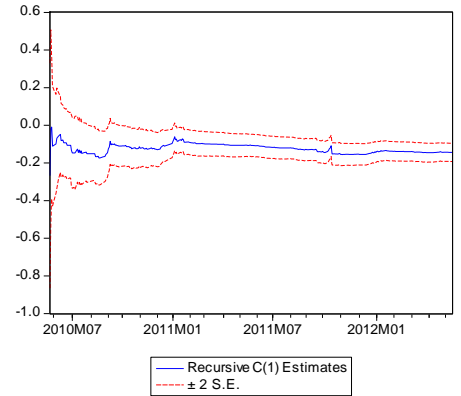

\section{Adaro}

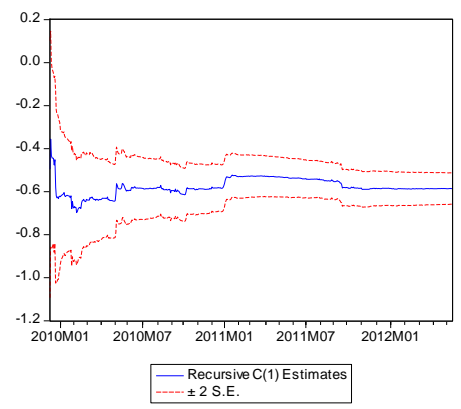

Indof

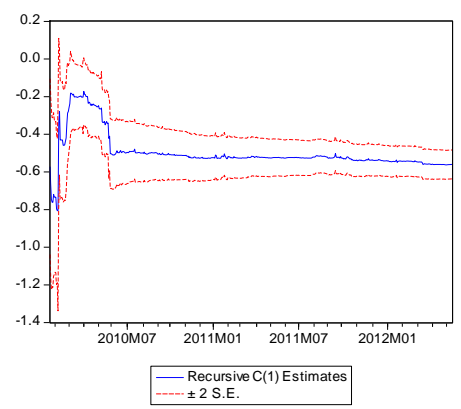

Semen

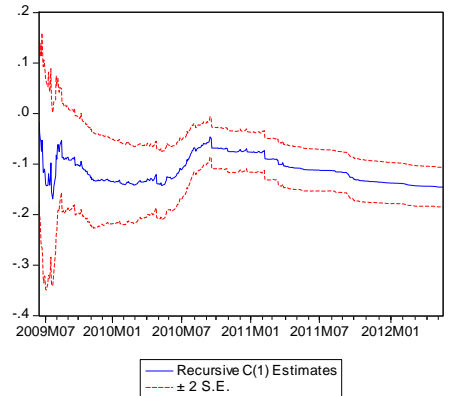

Bri

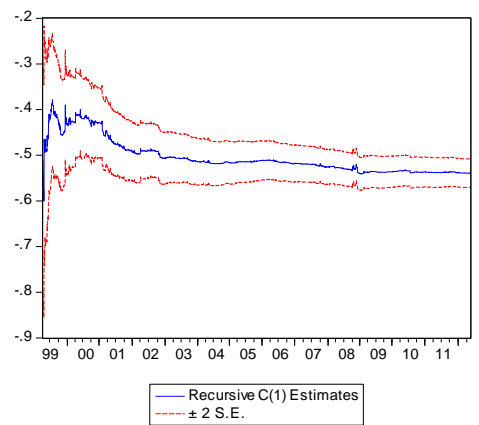

Indosat

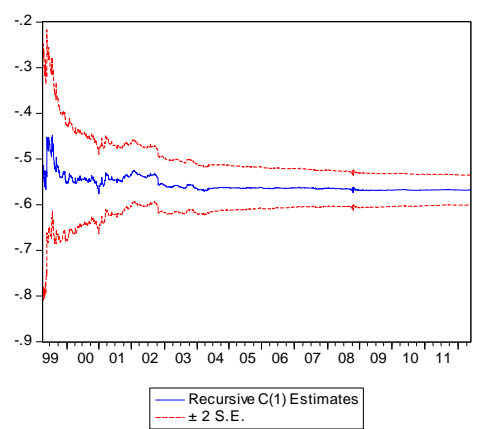

Tel

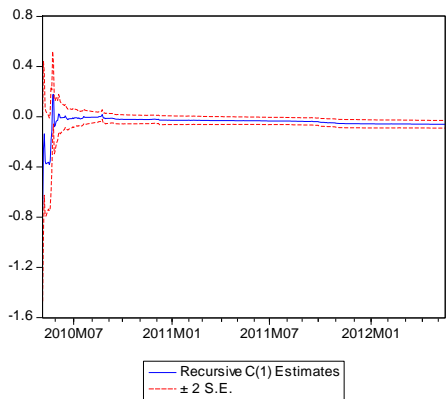

Bumi

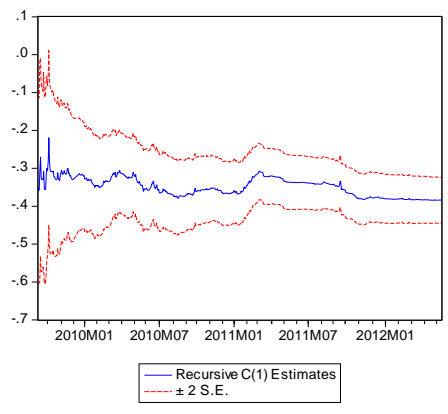

Mandiri

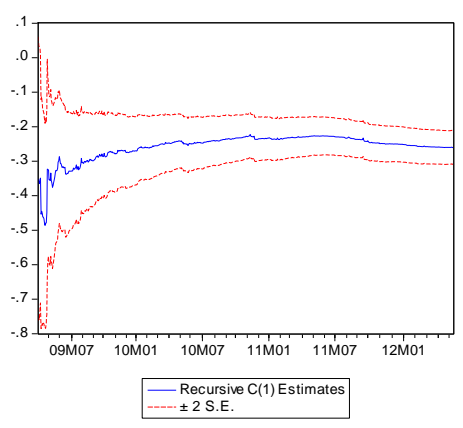

United

FigURE 8: THE SPEED OF ADJUSTMENT COEFFICIENTS $(B)$ - INDONESIA 

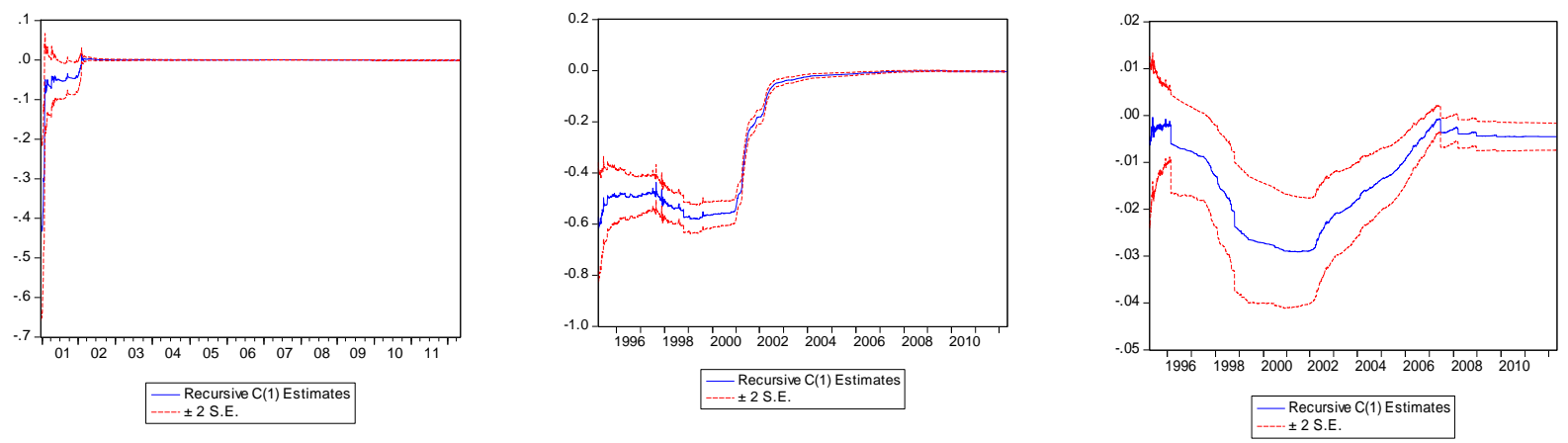

\section{Gent}

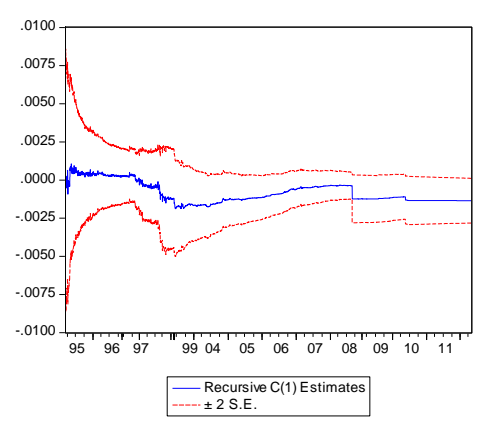

MBF

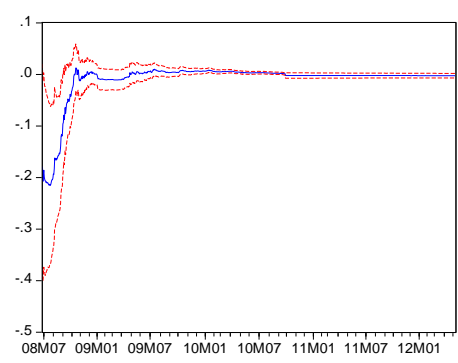

-Recursive C(1) Estimates
---- \pm 2 S.E.

\section{Gentmsia}

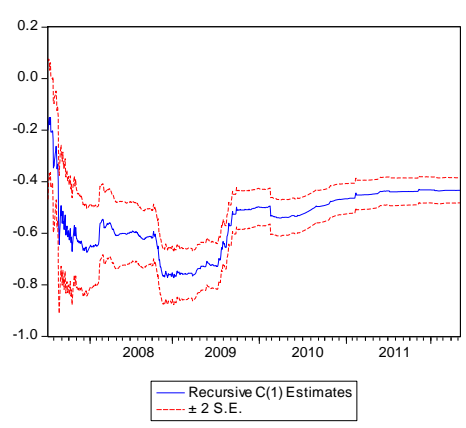

Mbnk

\section{KLKep}

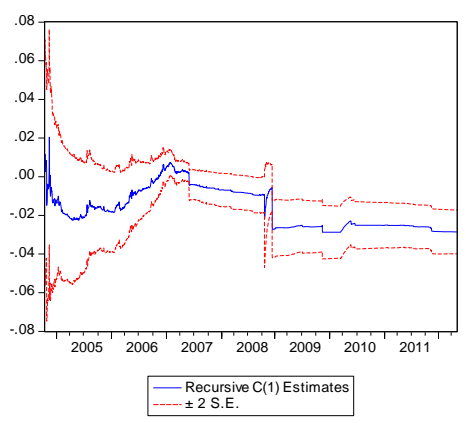

TNB

Top

Figure 9: THE SPEED OF ADJUSTMENT COEFFICIENTS $(B)$ - MALAYSIA 


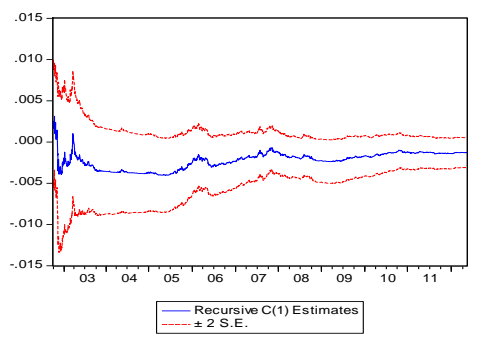

\section{Akbank}

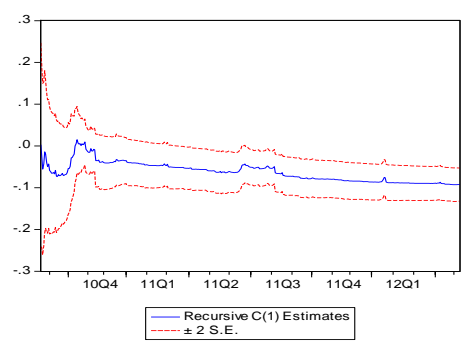

Ford

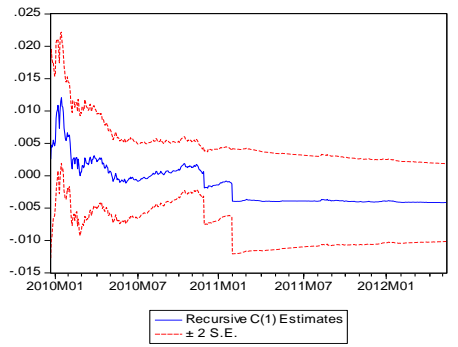

Tefken

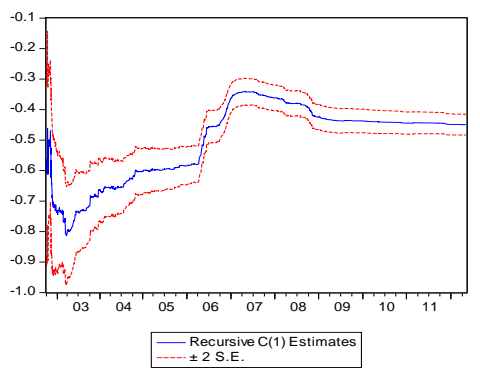

Turkcel

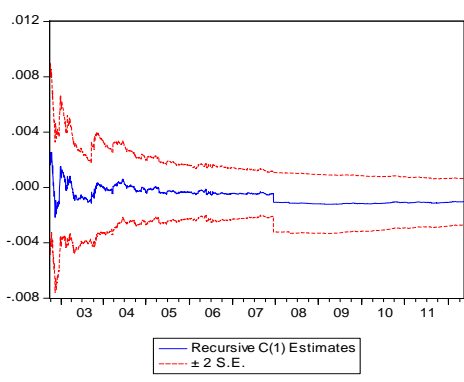

\section{Anadolu}

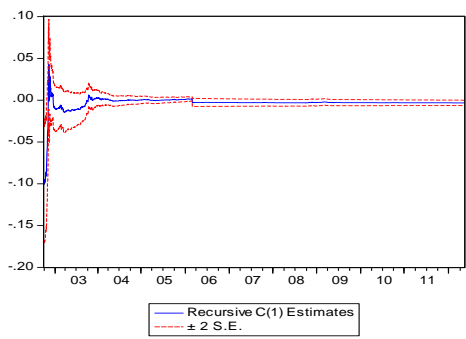

Haci

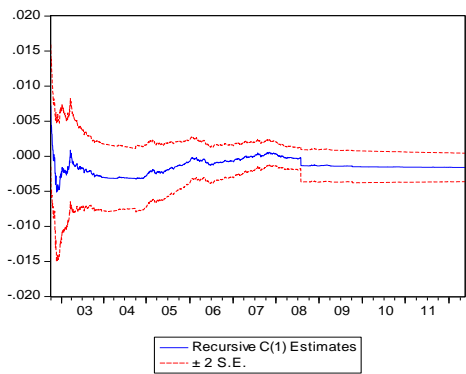

Tkig

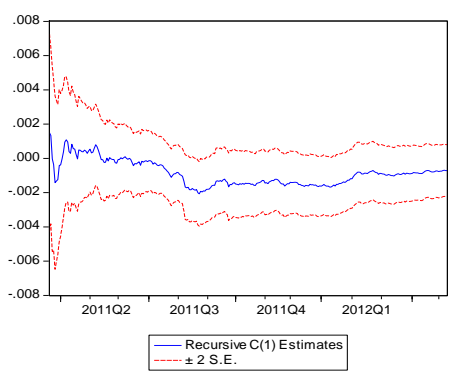

Turkhava

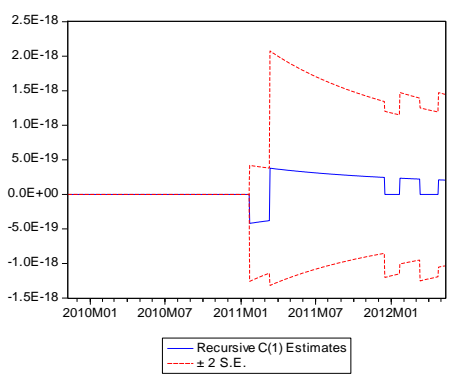

\section{Arcelik}

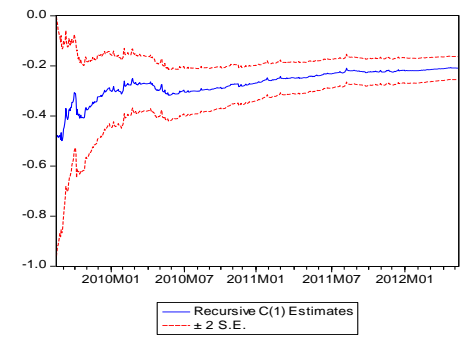

Koc

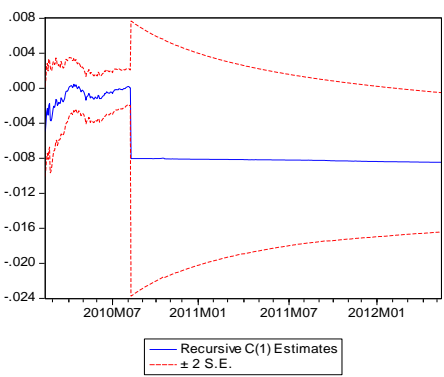

Tkiv

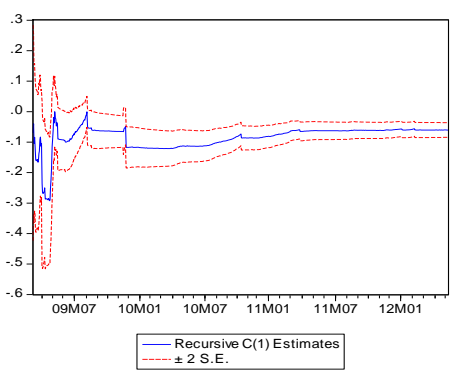

Turkiye

FIGURE 10: THE SPEED OF ADJUSTMENT COEFFICIENTS $(B)$ - TURKEY 


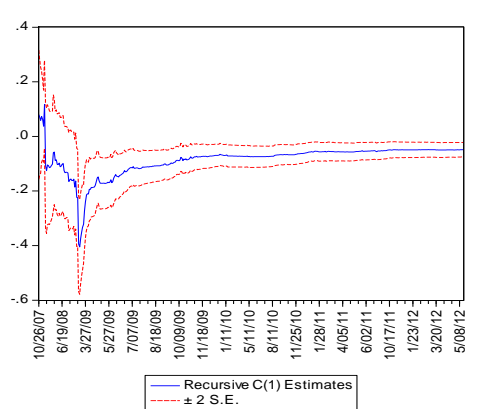

Bankau (Lebanon)

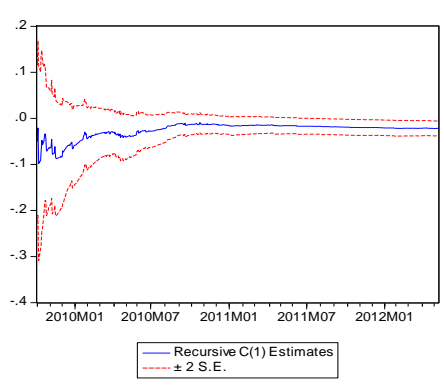

Guarte (Nigeria)

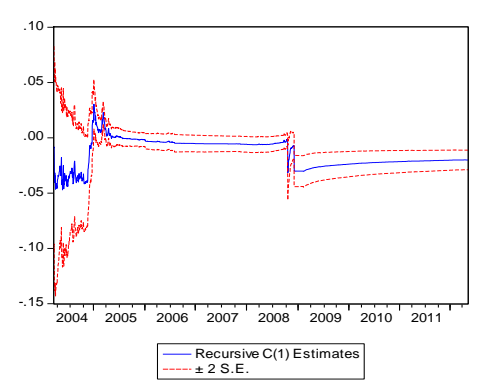

Qattel (Qatar)

FIGURE 11: THE SPEED OF ADJUSTMENT COEFFICIENTS $(B)$ - OTHERS

In sum, all these graphical evidence did not indicate a greater speed of financial integration between these home markets and cross-listed markets. This finding is similar to the research done by Gagnon and Karolyi (2010). They found that the convergence process was faster for countries with higher per-capita GDP, stronger investor protection, higher accounting standards, fewer short sale restrictions, and greater institutional ownership. Since most of the elements stated above were mainly qualities found in developed markets, this could be one of the plausible justifications of why there was no evidence of integration in these OIC markets (usually they fall under emerging markets).

\section{TABLE 6: SUMMARY RESULTS ON INTEGRATION}

\begin{tabular}{|l|l|}
\hline Test of Integration & Findings/Results \\
\hline Cointegration & $\begin{array}{l}\text { Only 53\% of the companies showed evidence of } \\
\text { cointegration. The companies were mainly from } \\
\text { Egypt, Indonesia, and Malaysia. }\end{array}$ \\
\hline Speed of convergence & $\begin{array}{l}\text { None of the companies showed any indications of } \\
\text { integration. }\end{array}$ \\
\hline
\end{tabular}

In summation, there were somewhat mixed results of this analysis (Refer to Table 6). One of the reasons for differing findings is because our studies had limitations in terms of data used in this study. The data were small in scale ${ }^{6}$ and more likely affected the quality of data ${ }^{7}$. This notion is fully supported by Karolyi (2006). Some evidence point to integration, while others indicate that the markets are segmented. Both outcomes have their own positive and negative effects. For example, firms in the markets that are not integrated or segmented will undoubtedly have more investment barriers. This will translate to higher risk, price, and cost of capital. The way to mitigate these adverse effects is to adopt policies (in this case, cross-listing) that promote the positive impact of international diversification (Arouri \& Foulquier, 2012; Leuz, 2003). If there is integration, the region will benefit through more efficient capital allocation, less probability of asymmetric shocks, a more robust market framework, and help improve the capacity of the economies to absorb shocks and foster development.

Nonetheless, without integration or when the markets are segmented, does have its benefits. These markets (OIC markets) posit to have better diversification and reduce risk of cross-border financial contagion, especially in the situation when the region's economies are dependent on one another ( $\mathrm{Yu}$ et

6 In this case due to the unavailability of data, we were only able to extract a small number of firms and also several countries.

7There were many missing data and some of these prices were unchanged for some time and maybe due to less trading days. The possible explanation could be that these prices were updated and followed the last price of trading day that was available. 
al., 2010). The less developed markets such as OIC markets are expected to provide better diversification opportunities compared to other developed markets since there is an option to invest in different markets, different securities, and different currencies. Claessens et al. (2002) stated that emerging stock markets have more appealing features in providing investment and diversification opportunities to investors. In another spectrum, the lack of integration could also be a reflection of a hindrance to access these markets.

\section{CONCLUSION}

In summary, the cross-listing via DRs produce some evidence of integration. In the case of OIC stock markets, the integration is preferred because if the markets are integrated, the cost of raising capital for the companies is low. Integration can improve local stock market liquidity. If markets are segmented, only local investors can trade in the local markets, whereas all international investors can trade in the local markets if the markets are integrated. Nonetheless, the evidence of integration can be seen either based on the countries or the type of company. A study by Sabri (2002) discovered that there are still major obstacles concerning the ability and willingness of Arab stock markets to attract international investors. He further suggested that Arab stock markets remove restrictions on foreign investment, improve the regulatory conditions, and reduce fees and bureaucracy to attract foreign investors. DRs could be one of the means to increase competition for these firms internationally.

Additionally, for international investors, investing shares via DRs could provide a platform for diversifying their portfolio. As mentioned earlier, the OIC countries are in a dire need to come up with a mechanism for enhancing cooperation and intra-investment among them. By having the DRs, these companies can tap into foreign markets with a lower cost of capital and increase competition.

\section{ACKNOWLEDGEMENT}

The authors would like to thank the Ministry of Higher Education, Malaysia for a generous grant under the Fundamental Research Grant Scheme (FRGS) (USIM/FRGS/IFWMI/32/52214).

\section{References}

Alaganar, V. T., \& Bhar, R. (2002). Information and volatility linkage under external shocks Evidence from dually listed Australian stocks. International Review of Financial Analysis, 11, 59-71.

Arouri, M. E. H., \& Foulquier, P. (2012). Financial market integration: Theory and empirical results. Economic Modelling, 29, 382-394.

Arquette, G. C., Jr., W. O. B., \& Burdekin, R. C. K. (2008). US ADR and Hong Kong H-share discounts of Shanghai-listed firms. Journal of Banking \& Finance, 32, 1916-1927.

Chan, K., Menkveld, A., \& Yang, Z. (2008). Information asymmetry and asset prices: evidence from the China foreign share discount. Journal of Finance, 63, 159-196.

Claessens, S., Klingebiel, D., \& Schmukler, S. (2002). Explaining the migration of stocks from exchanges in emerging economies to international centers. Working Paper, World Bank,Washington, DC.

Claessens, S., Lee, R., \& Zechner, J. (2003). The future of stock exchanges in European Union Accession Countries. Corporation of London, 1-35.

Doidge, C., Karolyi, G. A., Lins, K. V., Miller, D. P., \& Stulz, R. M. (2009). Private Benefits of Control, Ownership, and the Cross-listing Decision. The Journal of Finance, 64(1), 425-466. doi: 10.1111/j.1540-6261.2008.01438.x

Froot, K., \& Dabora, E. (1999). How are stock prices affected by the location of trade? Journal of Financial Economics, 53, 189-216.

Gagnon, L., \& Karolyi, G. A. (2010). Multi-market trading and arbitrage. Journal of Financial Economics, 97, 53-80.

Hassan, M. K., \& Suk Yu, J. (2007). Stock Exchange Alliances in Organization of Islamic Conferences (OIC) Countries (pp. 30): Indiana State University.

JP Morgan. (2010). Depositary Receipts: Year in Review 2010: Worldwide Securities Services.

Karolyi, G. A. (2004). The Role of ADRs in the Development and Integration of Emerging Equity 
Markets. Review of Economics and Statistics 86 (3), 670-690.

Kato, K., Linn, S., \& Schallheim, J. (1991). Are there arbitrage opportunities in the market for American depositary receipts? Journal of International Financial Markets, Institutions and Money, 1, 73-89.

Leuz, C. (2003). Discussion of ADRs, Analysts, and Accuracy: Does Cross-Listing in the United States Improve a Firm's Information Environment and Increase Market Value? Journal of Accounting Research, 41(2), 347-362. doi: 10.1111/1475-679x.00107

Yeyati, L., Schmukler, S. L., \& Van Horen, N. (2009). International financial integration through the law of one price: The role of liquidity and capital controls. Journal of Financial Intermediation, 18(3), 432-463. doi: 10.1016/j.jfi.2008.09.004

Martin, J. (1995). The return of ADRs. Euromoney (320), 101-101.

Pascual, A. G. (2003). Assessing European stock market cointegration. Economics Letters, 78, $197-203$.

Rosenthal, L., \& Young, C. (1990). The seemingly anomalous price behavior of Royal Dutch/Shell and Unilever N.V./PLC. Journal of Financial Economics, 26, 123-141.

Sabri, N. R. (2002). Cross-listings of stocks among European-Arab (Mediterranean) markets. Finance India, 16(1), 205-227.

Sevic, A., Krishnamurti, C., \& Sevic, Z. (2010). Determinants of choice of depositary receipt programs: An exploratory study. Managerial Finance, 36 (12), 990-1006.

Torre, A. d. 1., Valdez, J. C. G., \& Schmukler, S. L. (2005). Stock Market Development under Globalization: Whither the Gains from Reforms? (pp. 42): World Bank.

Wahab, M., Lashgari, M., \& Cohn, R. (1992). Arbitrage opportunities in the American depositary receipts market revisited. Journal of International Financial Markets, Institutions and Money, 2, 97-130.

World Bank. (2006). World Development Indicators: World Bank, Washington D.C.

Yu, I. W., Fung, K. P., \& Tam, C. S. (2010). Assessing financial market integration in Asia - Equity markets. Journal of Banking and Finance, 34(12), 2874-2885. doi: 10.1016/j.jbankfin.2010.02.010 


\section{APPENDIX 1}

Sample of Home and Cross Listed Shares Used in Price Parity Analysis

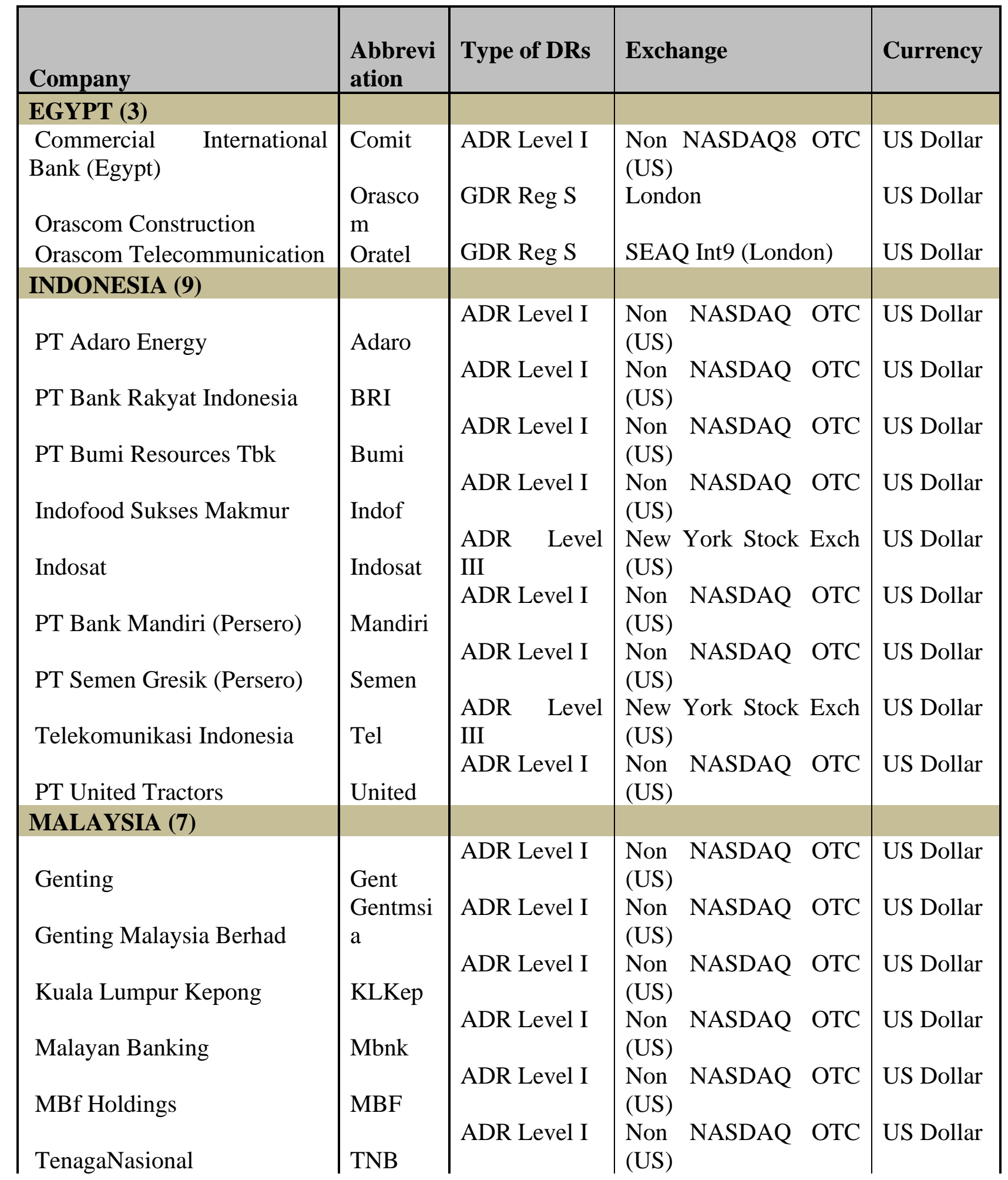

8 It is one of American stock markets. "NASDAQ" originally stands for National Association of Securities Dealers Automated Quotations. It is the second largest stock market compared to official stock exchanges by market capitalization in the world, after the New York Stock Exchange. Retrieved April 13, 2013 from http://en.wikipedia.org/wiki/NASDAQ

9 The Stock Exchange Automated Quotation system (or SEAQ) is a system for trading mid-cap London Stock Exchange (LSE) stocks. Retrieved April 13, 2013 from http://en.wikipedia.org/wiki/SEAQ 


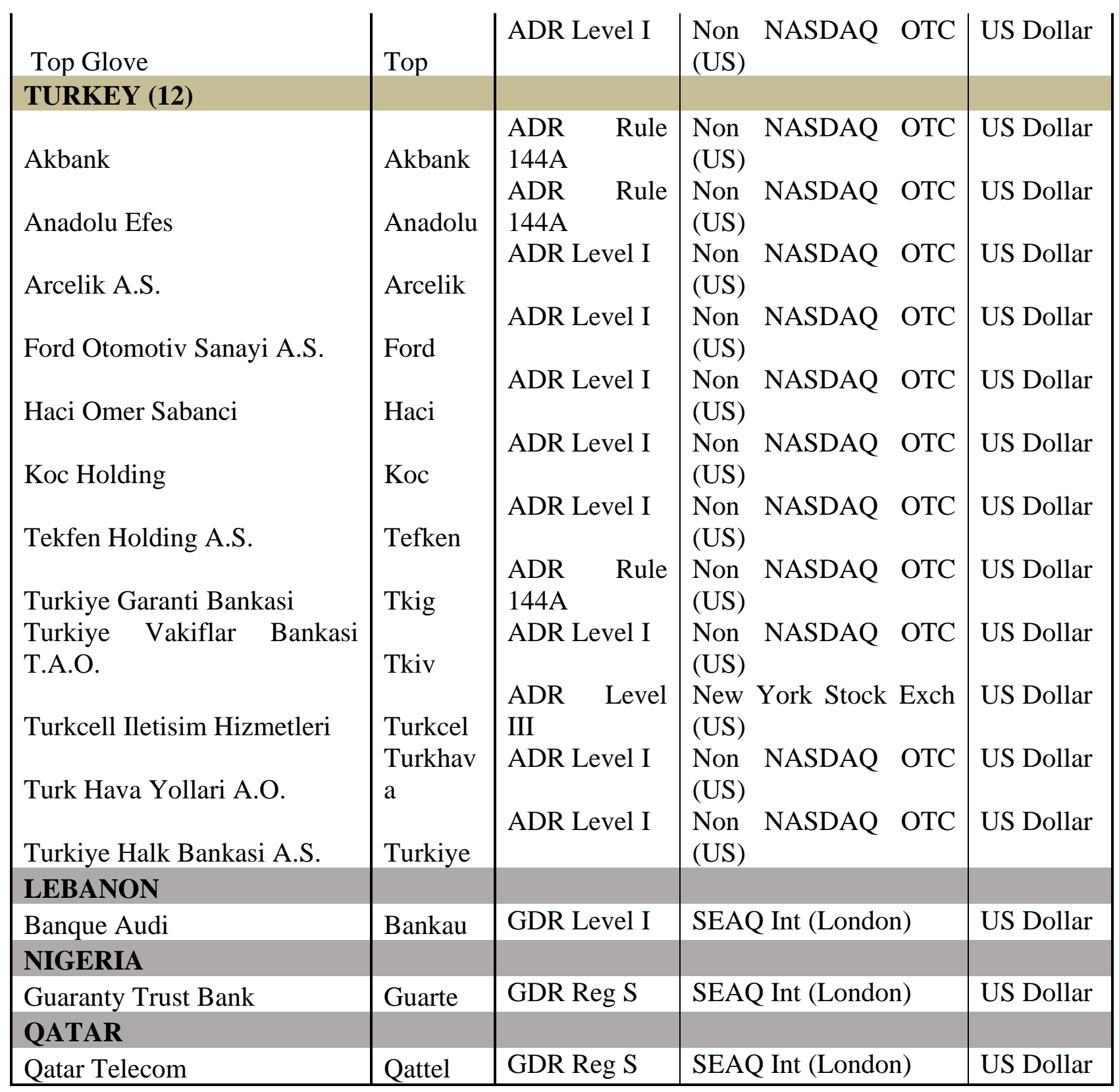


